\section{The Claromontanus Stichometry and its Canonical Implications}

\section{Kelsie G. Rodenbiker}

Theology and Religious Studies, University of Glasgow, Scotland
Journal for the Study of the New Testament 202I, Vol. 44(2) 240-253

(C) The Author(s) 2021

(c) (i)

Article reuse guidelines: sagepub.com/journals-permissions DOI: | 0.1 | 777/0 |42064X2 | 1055647 journals.sagepub.com/home/jnt

@SAGE

\begin{abstract}
The stichometric list inserted into the sixth-century Codex Claromontanus presents a NT list of 27 books, but not the familiar canonical collection. Alongside one OT (Judith) and five NT titles (ad petrum prima, Barnabas, the Shepherd, the Acts of Paul, and the Revelation of Peter) horizontal dashes have been placed, which are commonly said to denote secondary status. A history of misunderstanding surrounding these obeli, originating with Tischendorf in the nineteenth century, has obscured the stichometry's role in the history of the NT canon. This article traces that history, showing that the later addition of the obeli indicates precisely the opposite of what has often been claimed of the stichometry - that it should resemble nearly or exactly the later-canonized NT list. Rather, the original inclusion of four alternative scriptural texts in the stichometry indicates a lasting interest in such texts and the continued elasticity of the NT canon.
\end{abstract}

\title{
Keywords
}

Canon, Claromontanus, early Christian manuscripts, obelus, stichometry

\section{The Claromontanus Stichometry}

In 1852, Constantin Tischendorf published his transcription of a sixth-century codex of the Pauline epistles, the Codex Claromontanus, copied from the manuscripts held at the Bibliothèque Nationale de France (Tischendorf 1852). ${ }^{1}$ His

1. The stichometry is transcribed on pp. 468-69; notes on p. 589 .

\section{Corresponding author:}

Kelsie G. Rodenbiker, Theology and Religious Studies, University of Glasgow, 4 The Square, Glasgow, Scotland.

Email: kelsie.rodenbiker@glasgow.ac.uk 
transcription appears to have quickly become the authoritative edition to which to appeal.

The Codex Claromontanus (D 06) was written in parallel Greek (verso) and Latin (recto), and a Latin stichometric list was copied onto two and a half of the four pages that separate Philemon and Hebrews (467v-468v). Due to differing handwriting and ink, it has been determined that this list and the Pauline letters were not copied by the same scribe - even a cursory comparison would seem to confirm this, as the size, shape, spacing and color of the lettering is visibly distinct. $^{2}$ Stichometries like this one are scribal aids that provide the approximate line length of the listed works, so that scribes know how much space to allow for each text, and thus the list is in two columns: text titles on the left and the stichometric numbers on the right (only the titles are provided in Table 1). The Claromontanus stichometry, titled 'VERSUS SCRIBTURARUM SANCTARUM', presents an apparently 'whole' Bible, with both Old and New Testament texts, though the only distinguishing factor between the Testaments is a heading preceding the four gospels. The OT collection does not include 1 and 2 Chronicles, the third book of Maccabees, Lamentations or Baruch. ${ }^{3}$ Headings are consistently used to designate sub-collections or text units: 'Regnorum' precedes the four books of Kingdoms and 'Maccabeorum sic. [thus]' precedes the three included books of Maccabees, while 'euangelia IIII' precedes the four gospels, in the order of Matthew, John, Mark, Luke', and 'epistulas Pauli' precedes the Pauline letters (and indeed the rest of the list, as this is the final heading).

Table I. The Claromontanus stichometry, BnF Grec. 107 868-870 / 06 467v-468v

\begin{tabular}{|l|l|l|l|}
\hline $467 \mathrm{v}$ & & $468 \mathrm{r}$ & $468 \mathrm{v}$ \\
\hline genesis & ossee & ester & iacobi \\
\hline exodus & amos & iob & pr. iohanni epist. \\
\hline leviticum & micheas & tobias & iohanni epistula II \\
\hline numeri & ioel & euangelia IIII & iohanni epistula III \\
\hline
\end{tabular}

(Continued)

2. The stichometry (and entire codex) can be viewed on the Bibliothèque nationale de France website: http://gallica.bnf.fr/ark:/12148/btv1b84683111/f868.item, from 467v to 468v (868$870 \mathrm{BNF}$ view).

3. It is possible, however, that Lamentations and Baruch are subsumed under Jeremiah, rather than altogether omitted. Thanks are due to Jeremiah Coogan for this suggestion.

4. This order, very similar to the traditional western order of Matthew, John, Luke, Mark, may prioritize apostolicity over date. By the fourth century, the traditionally eastern order of Matthew, Mark, Luke, John appears to have become so ubiquitous that it was unnecessary to argue for their particular order (cf. Origen, who lists Matthew, Mark, Luke, John, Comm. Matt. 1.3-6; Hom. Josh. 7.1, Eusebius names only 'the holy gospel tetrad' in Hist. eccl. 3.25.1; Cyril of Jerusalem presumably assumes the fourfold gospel, Catechesis 4.36; and Athanasius lists them without argument in Epist. fest. 39.18. 
Table I. (Continued)

\begin{tabular}{|l|l|l|l|}
\hline deuteronomium & abdias & mattheum & iudae epistula \\
\hline iesu nauue & ionas & iohannes & - barnabae epist. \\
\hline iudicum & naum & marcus & iohannis revelatio \\
\hline rud & ambacum & lucam & actus apostolorum \\
\hline regnorum & sophonias & epistulas pauli & -pastoris \\
\hline primus liber & aggeus & ad romanos & -actus pauli \\
\hline secundus lib. & zacharias & ad chorintios I & -revelatio petri \\
\hline tertius lib. & malachiel & ad chorintios II & \\
\hline quartus lib. & eseias & ad galatas & \\
\hline psalmi dauitici & ieremias & ad efesios & \\
\hline proverbia & ezechiel & ad timotheum I & \\
\hline aeclesiastes & daniel & ad timotheum II & \\
\hline cantica canticorum & maccabeorum sic. & ad titum & \\
\hline sapientia & lib. primus & ad colosenses & \\
\hline sapientia Ihu & lib. secundus & ad filimonem & \\
\hline XII profetae & lib. quartus & —ad petrum prima & \\
\hline & -iudit & ad petrum II & \\
\hline & hesdra & & \\
\hline
\end{tabular}

The titles of the Pauline epistles move from Ephesians to 1 Timothy, omitting Philippians, 1 and 2 Thessalonians and Hebrews, and it has been suggested that this is one of a number of possible errors on the part of either the scribe or his exemplar. The codex itself, in fact, does include the works missing from the stichometry. The jump can be explained as an error in the transcription due to the similarity in the Greek titles of Hebrews ('Eßpaíous) and Ephesians ('Eфєбíous), and the issue would also be further complicated by the translation from a Greek exemplar to the Latin of the current list (Hahneman 1992: 142; Metzger 1997: 230). ${ }^{5}$ Following Philemon are two texts labeled ad petrum - tolfor rather than

5. It has also been suggested that Barnabas stands in for Hebrews in this list, as Barnabas was thought by some to have written Hebrews (cf. Tertullian, De pudicitia 20.2). The stichometric calculation for Barnabas (850 lines) also resembles more closely the length of Hebrews; see de Boer 2014: 252; Westcott 1855: $576 \mathrm{n}$. 1. If this list originated in an eastern context, as Harnack insists, Barnabas must be 'rebranded' as Hebrews; von Harnack 1893: 88. We would, however, expect Barnabas-as-Hebrews to be situated either among or at the end of the Pauline epistles due to its circulation with the Pauline corpus, rather than following Jude. And, because Barnabas was sometimes identified as a 'catholic epistle' (Origen, Contra Celsum 1.63.9), it is more likely that it is Barnabas, not Hebrews, that is meant here. Against the insertion of Hebrews, see also the discussion of Barnabas among the catholic epistles in Nienhuis 2007: 75. 
from/of Peter - perhaps intending 1 and 2 Peter, given their placement after the Pauline epistles and before the rest of the catholic epistles, and which will be further discussed below. While a catholic epistle collection is not explicitly designated here, 1 Peter's prominence among early Christian literature would suggest that the transition from Paul's letters to those of Peter (rather than James's placement at the start of the non-Pauline epistles) is not surprising (Nienhuis 2007: 77). Consistent with this stichometric ordering, the codex also has the

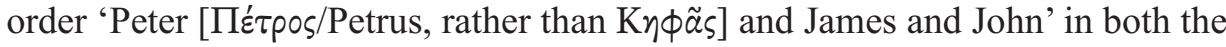
Greek and Latin transcriptions of Gal. 2.9.

\section{A History of Misunderstanding}

Beginning with Tischendorf's transcription of Claromontanus, it has been commonly assumed that there exist only four dashes - those alongside Barnabas, the Shepherd, the Acts of Paul and the Revelation of Peter - and that these are intended to denote secondary status. Tischendorf's edition (1852: 589 n. 69.6.9.10.11) includes just this one small footnote on the existence of the obeli: 'By these four line-enumerations for epist. Barnabas, Shepherd, Acts of Paul, Revelation of Peter obeli have been placed by a fairly recent hand'. ${ }^{6}$ Tischendorf was correct to note that these obeli were inserted by a later hand, but mistaken in listing just these four texts as having been set apart. All six marks are absent from Tischendorf's transcription, and, while transcriptions excluding critical marks were apparently standard practice, the authority of Tischendorf's 'dashless' edition continues to hold significant sway. Whether due to his own 'scribal omission', error, canonical bias or another reason, why he chose to name only four texts, rather than six, as having been marked with an obelus remains a mystery. There are a number of inherited assumptions regarding the obeli that contribute to many taking for granted that the stichometry is simultaneously rife with scribal errors and that it intentionally presents a list of layered authority in which only the four now-non-canonical texts are attributed secondary or disputed status. What will emerge is that, while scribal error may indeed be to blame for a few of the list's 'peculiarities' (Metzger 1997: 230), the history of scholarship has left something to be desired in the way of discussion surrounding the obeli.

Westcott (1855: $578 \mathrm{n}$. 2), writing just a few years after Tischendorf published his transcription, cites a small footnote by Tischendorf, having marked in his own listing only Barnabas, the Shepherd, the Acts of Paul and the Revelation of Peter. Zahn also cites Tischendorf as the source of his knowledge about the codex,

6. 'His quattuor versibus de epist. Barnabae, pastore, actibus Pauli, revelatione Petri manu satis recenti praepositi sunt obeli.' The numerals $6,9,10$ and 11 correspond to the lines of the stichometry on which the four texts whose obelus Tischendorf acknowledges are transcribed (on p. 469). 
though he is quick to identify and to correct small errors or idiosyncrasies in Tischendorf's edition, and even in the manuscript itself. Regarding the dashes alongside Barnabas, the Shepherd, the Acts of Paul and the Revelation of Peter, Zahn (1890: $157-58$ n. 2 ; 1929: 81-82) comments that, "the interpretation as critical obeli is undoubtedly correct; but I doubt that the age of such small strokes can be judged. Tischendorf's superb transcription gives no clear picture of the appearance of the Codex in general, nor at this point, where it matters in particular. ${ }^{7}$ In a later publication, an outline of his Geschichte des Neutestamentlichen Kanons, Zahn further comments that by the marks alongside these titles the scribe wanted to express that 'in his view or in the ecclesiastical custom of his environment', these texts 'do not belong to sacred scripture' (Zahn 1929: 82 n. 2). ${ }^{8}$

Harnack does not comment on the presence of the five obeli in the NT portion of the list. Proceeding with his commentary on the catalogue as if every text present was considered to have been fully authoritative by the original scribe, he even refers to the scribe's inclusion 'without comment' of the six texts following the catholic epistles (Harnack 1893: 86). Harnack presents the list in what was perhaps its original state - fully inclusive of four now-apocryphal texts. Souter, a few decades later, returns to Tischendorf's view, describing a 'canon of unknown date and provenance in the "Codex Claromontanus" written in the sixth century (perhaps in Sardinia)', and listing only the NT portion. 'There can be little doubt', he says, 'that Phil., 1 Thess., 2 Thess. should be inserted here. The faults in the numbers of lines show that the scribe was careless' (Souter 1935: 211 n. 1). Souter inserts obeli only alongside Barnabas, the Shepherd, the Acts of Paul and the Revelation of Peter, noting that, 'the horizontal line represents that the scribe regarded the four works thus indicated as not on the same plane as the others' (Souter 1935: 212 n. 1).

As early as 1852, then, Tischendorf appears to be the originator of both the identification of just four texts (excluding Judith and 1 Peter) as the ones marked with an obelus, as well as the suggestion that the obeli are secondary, rather than original to the Claromontanus stichometry or its exemplar (Tischendorf 1852: $468-69,589)$. The former assertion was taken on board by subsequent scholarship, whereas his brief suggestion that the dashes are secondary was ignored until Verheyden, much more recently, made an equally brief reference to 'four

7. 'Über die Striche zur Seite der Titel in I. 70. 73. 74.75 bemerkt Tischendorf p. 589 manu satis recenti praepositi sunt obeli. Die Deutung als kritischer obeli ist zweifellos richtig; dass aber das Alter so kleiner Striche beurtheilt warden kann, bezweifele ich. - Tischendorfs prächtiger Druck gibt von dem Aussehen des Codex überhaupt und an dieser Stelle, wo es darauf ankommt, insbesondere kein anschauliches Bild.'

8. 'Der Strich links von diesem und von den 3 letzten Titeln ist ein kritisches Zeichen, wodurch der Schreiber der Hs ausdrücken wollte, dass der Brief des Barnabas, der Hirt des Hermas, die Akten des Paulus und die Apokalypse des Petrus nach seiner Meinung oder dem kirchlichen Brauch seiner Umgebung nicht zu den scripturae sanctae gehören.' 
extra-canonical books that are marked (by a second hand?) by a dash ...' (Verheyden 2013: 402 n. 22). ${ }^{9}$ However, even Verheyden does not mention the anomalous titles for 1-2 Peter or that the same dash can also be found next to both Judith and ad petrum prima.

Due to the inherited assumptions that only the now-apocryphal texts in the stichometry are marked with obeli and that these marks are original to the list, modern scholarship has also tended to assume that the list puts forth something that looks very similar to the now-canonical NT. In his 1986 dissertation on Eusebius's role in the formation of the NT canon, Gregory Allen Robbins observes a connection between the stichometry inserted into the Codex Claromontanus and Eusebius's canon list detailed in Hist. eccl. 3.25, noting that four of the texts Eusebius identifies as vó $\theta a$ are included in the stichometry, as well, and that this list, like Eusebius's, distinguishes some supposedly secondary texts from fully accepted ones. He claims that the Codex Claromontanus 'given its careless omissions, apparently intends to set forth a 27-book "New Testament"' (Robbins 1986: 233). ${ }^{10}$

Robbins is by no means alone in his observation that the stichometry should look a lot more like what became the NT canon list - he is following the likes of Zahn and Souter and is subsequently followed by Metzger and Hahneman. In a discussion about the status of the Shepherd in ancient canon lists published six years after Robbins finished his dissertation, Hahneman claims, also noting the likeness to Eusebius's vó $\theta$ a grouping, which denotes secondary but not heretical status, that 'the scribe drew a line before the last four entries, namely Barnabas, the Shepherd, the Acts of Paul, and the Revelation of Peter' (Hahneman 1992: $67,141) .{ }^{11}$ He does not mention the obeli alongside Judith or ad petrum prima, nor is he correct that it is the final four texts that are marked - the Revelation of John and the Acts of the Apostles separate Barnabas from the Shepherd, the Acts of Paul and the Revelation of Peter (Hahneman 2002: 141).

Metzger (1997: 230, 310 n. 9) alternatively claims that the obelus beside 1 Peter may be a 'paragraphus', a Greek paragraph mark to distinguish 1 Peter and the following texts from the Pauline epistles, while the other four 'identify works of doubtful or disputed canonicity', and he also assumes the same scribe

9. Aside from Verheyden's footnote, the New Cambridge History of the Bible lacks any mention of the Codex Claromontanus and its stichometric list.

10. Harnack also observes this likeness between the Claromontanus stichometry and the texts rejected by Eusebius in HE 3.25; Harnack 1893: 84-88. An article comparing the NT canon formation to intercultural construction likewise claims that the stichometry sets forth a 27-book list, but rather than the familiar NT canon this one includes Barnabas, the Shepherd, the Acts of Paul and the Revelation to Peter instead, omitting, as the scribe does, Philippians, 1-2 Thessalonians and Hebrews: Loba Mkole 2016: 245.

11. He also attributes the absence of Philippians and 1-2 Thessalonians to scribal omission, along with the carelessness shown by the 'confusing stichometry' for 2 Corinthians and 1 Timothy. 
who copied the list also placed the obeli. This proposal is inconsistent with the rest of the stichometry, however, throughout which headings and a break in stichometric numbering are used to begin a new section: the gospels are distinguished from the OT list by the title 'Euangelia IIII' and, similarly, the Pauline epistles are separated from the gospels by the designation 'Epistulas Pauli' ${ }^{12}$ No title or break in stichometric numbering separates the Pauline epistles from the texts that follow Philemon. Little has changed since Tischendorf's transcription and publication of the Codex, and Harnack appears to be the only significant outlier in identifying the four now-apocryphal texts as original to the Claromontanus stichometry - despite, or perhaps even because of, his lack of discussion of the obeli.

Despite the interest in the canonical process, more recent works either do not mention Claromontanus or recapitulate old evidence without further comment. In a 2018 volume by Gallagher and Meade on the canon lists of early Christianity, the authors omit the obelus alongside Judith from their transcription of the stichometry (Gallagher and Meade 2018: 185), while following Metzger in identifying the obelus alongside ad petrum prima as a marker of separation from the Pauline epistles (Gallagher and Meade 2018: 186 n. 62). They then note that ' $[\mathrm{b}]$ eside the references to the Epistle of Barnabas, the Shepherd, the Acts of Paul, and the Revelation of Peter, there is a horizontal stroke extending into the left margin. This mark resembles an obelus, which usually indicated the spurious nature of the words so marked' (Gallagher and Meade 2018: 186 n. 65). They also note that the omission of 3 Maccabees and 1-2 Chronicles, as well as the missing Pauline epistles, is accidental (Gallagher and Meade 2018: 184 n. 51; 185 n. 59). Thus, '[t]he New Testament contains most of the books in the traditional twenty-seven-book New Testament, without Philippians, Thessalonians, and Hebrews' (Gallagher and Meade 2018: 184). Gallagher and Meade's research has recently been built on by Michael Dormandy in a 2018 article, in which he identifies the Codex Claromontanus as one among the 'common' fourth-century canon lists that 'closely resemble the modern canon', both removing the Codex Claromontanus from its sixth-century context and assuming its list is representative of the now-canonical NT (Dormandy 2018: 3). Misrepresentations of the Claromontanus stichometry have thus continued into current publications.

Overall, the inherited assumptions are threefold: first, that the Claromontanus stichometry is rife with scribal errors and omissions; second, that only those four texts now considered extracanonical are marked with a dash or obelus intended to indicate secondary or disputed status (not Judith or ad petrum prima); and third, that the obeli are original to the list. Taken together, these claims lead to the assumption that the stichometry meant to - though in its actual form it does not

12. 'REGNORUM' also labels 1-4 Kingdoms, and MACCABEORUM does the same for I, II and IIII Maccabees. 
- present a list of NT texts very close to or exactly matching the 27-book canonical NT. In order to associate the Claromontanus stichometry as closely as possible with what became the NT list, one must take a number of things for granted: (1) that Philippians, 1-2 Thessalonians and Hebrews are omitted due to error, not intention; (2) that ad petrum prima and ad petrum II refer to the canonical Petrine letters, despite the label for/to Peter, rather than from/of; (3) that the obelus alongside what is supposedly 1 Peter is there to distinguish it and the texts that follow from the Pauline letters, despite the differing convention earlier in the list to denote the start of a new section; (4) that the dash alongside Judith either denotes secondary status or is an anomaly, given that no other OT texts are marked in this way, ${ }^{13}$ (5) that the dash alongside ad petrum prima is distinct from those by Barnabas, the Shepherd, the Acts of Paul, the Revelation to Peter and Judith, despite the uniformity of all six marks; (6) that the marks next to Barnabas, the Shepherd, the Acts of Paul and the Revelation of Peter do denote secondary or disputed status, and that of these four texts alone (not Judith or ad petrum prima); and (7) that the same hand who transcribed the stichometry also placed the marks alongside these five texts, explicitly intending for them to be received differently.

Scribal error may indeed play a role in the transmission of the stichometry even disregarding any bias towards the final form of the canon, the omission of Philippians, 1 and 2 Thessalonians and Hebrews from a list of Pauline epistles would be an odd choice, particularly since these texts are included in the very codex into which this stichometry was copied! The exclusion of these four letters and the mislabeling of 1-2 Peter as ad petrum prima and ad petrum II (not a random mislabeling but one influenced by the preceding items such that the scribe continued to copy these as if they were also Pauline letters) are likely genuine errors. My main point of contention lies with the traditional discussion of the obeli, namely that they are taken to be original to the list, while the marks

13. Judith is listed by Athanasius among the books that, while not 'canonized', can be read by new converts for their instruction (Epist. fest. 39.20). However, so are the Wisdom of Solomon, Sirach, Tobit, the Shepherd, and the Didache; Brakke 2010: 61. Aside from the Didache, these are also all included in the Claromontanus stichometry, with only the Shepherd also marked by the hand who obelized Judith and the five NT titles. In the Prologus Galeatus, Jerome likewise grouped Judith, with the Wisdom of Solomon, Sirach, Tobit and the Shepherd, among the apocrypha (and wrote prefaces only for Judith and Tobit); Gallagher and Meade 2018: 202. However, Jerome noted in his preface to the Vulgate text of Judith that, while 'Hebrew speaking Jews' counted the book among the apocrypha, since the Nicene Council placed it among the 'sacred texts', he conceded and translated it; Coletti and Lähnemann 2010: 43. There do not appear to be other reservations about Judith, and it is included, for example, in the earliest versions of the Syriac Peshitta. Thus, the obelizing scribe may have marked Judith in accordance with Jerome's remarks about its apocryphal status in his preface to the Vulgate text (and he either liked Tobit or forgot about its preface). The original scribe included Judith in the list without reservation, just as in the case of the obelized NT titles. 
alongside Judith and 1 Peter, the former of which has gone unnoted, including by Tischendorf, are assumed to be distinct from the others. This stichometry originally presented a 27-book list representative of a NT fully inclusive of Barnabas, the Shepherd, the Acts of Paul and the Revelation of Peter.

\section{An Alternative New Testament}

While it is not my main purpose here to provide a comprehensive account of the Codex Claromontanus and its entire stichometry, a brief word about its history will prove relevant to both the use of obeli and the canonical discussion. It cannot be taken for granted that the list is in any way tied to the Pauline collection of the codex, considering it appears to have been transcribed after the codex itself was complete. However, because the four blank pages separate Philemon from Hebrews - the final book in the Claromontanus collection - the space could be an indication of the status of Hebrews as Pauline, due to its circulation with the collection, but not written by Paul. Still, between two books, rather than at the beginning or end of the corpus, would be unlikely for the intentional placement of the stichometric list of scriptural texts, and it remains most likely that the list was inserted after the complete transcription of the Pauline texts. A Latin translation from a Greek original could make particular sense since the codex itself is in Greek/Latin parallel.

As early as the third century BCE in a pre-Christian context (Aristarchus's commentary on Homer), and at least by the fourth century CE in a Christian context (correctors of major uncial manuscripts in the fourth century), obeli are used to designate words or phrases of questionable status. In his Commentary on Matthew, Origen explains that he used obeli and asterisks in the Hexapla to denote differences between the Septuagint, the Hebrew OT and other Hebrew manuscripts: words or passages occurring in the Septuagint but not the Hebrew text Origen marked with an obelus; he marked with an asterisk words not occurring in the Septuagint but inserted 'from other versions in agreement with the Hebrew', not 'daring' to remove anything completely. These differences, he posits, resulted 'either from the laziness of certain scribes or from the daring of some mistaken [scribes], or from the neglect of the correction of the scriptures, or from those who, in correcting in accordance with their own opinions, added or subtracted things'. ${ }^{14}$ The use of obeli in the context of a canon list, however, not only to designate portions of texts, may be unique to the Claromontanus stichometry.

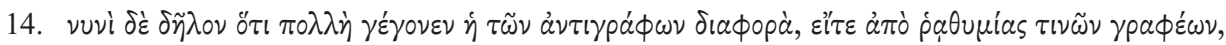

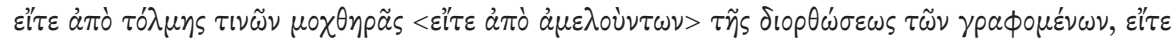

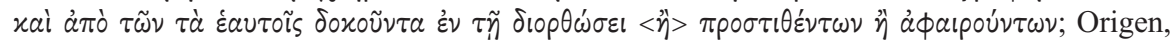
Comm. Matt XV.14.85-114 in Klostermann 1899 (my translation). See also Young 1997: 82-89. 
The obeli present in this stichometry alongside Judith, ad petrum prima, Barnabas, the Shepherd, the Acts of Paul and the Revelation of Peter do appear to be critical marks that indicate the questionable status of the marked titles, added by another hand sometime after the transcription of the stichometric list itself - that is, in the sixth century at the earliest.

The list may have originated in an eastern context sometime around the turn of the third to the fourth century, though it is crucial to note that this 'original' exemplar remains a theoretical one (Metzger 1997: 310; Gallagher and Meade 2018: 183). Metzger (1997: 230), referencing Zahn and Harnack, further notes that the stichometry witnesses to the influence 'from the East making its way into the West', which reflects a situation 'midway between Clement of Alexandria and Origen on the one side and Eusebius and Athanasius on the other'. Hahneman (1992: 68, 141-43) moves the date forward, seeing the list as an intermediary between Eusebius and Athanasius. Noting both sides, Meade and Gallagher observe that those who emphasize an earlier date do so on the basis of features that would be considered more unusual the later the proposed date, such as the inclusion of four now-non-canonical texts, while advocates for a later date do the opposite, emphasizing features that would appear unusual in the early fourth century (Gallagher and Meade 2018: 183). The latter position, exemplified by Hahneman (1992: 67, 143), who is keen to shift the provenance of the list into the fourth century, emphasizes the 'absence of reservation' about the catholic epistle collection. However, there is no reason why this should not just as likely suggest that such a list pre-dates Eusebius, particularly considering Eusebius is aware of a seven-letter collection of catholic epistles, and that even the five disputed letters in this collection are 'known to many' and 'publicly read in most churches' (Hist. eccl. 3.35.3; 2.23.25).

As we have seen, it has been suggested that this list is so riddled with scribal error and omissions that it likely should contain the 27-book NT canon many have come to expect. In fact, the stichometry shows remarkable correspondence to the NT list rejected by Eusebius in Hist. eccl. 3.25.4-5, where he names the now-canonical 27 books, along with the Acts of Paul, the Shepherd, the Apocalypse of Peter, the Epistle of Barnabas, the Didache and the Gospel of the Hebrews - a possible (but, in his view, incorrect) 33-book NT. He is not simply listing spurious texts but is opposing a larger canon in favor of a more minimal 21-book NT, also excluding the five disputed catholic epistles (James, Jude, 2 Peter, and 2-3 John) and the Revelation of John. A NT comprised of 27 texts is not, for Eusebius, on the table. Perhaps the most crucial element of the argument that the Claromontanus stichometry presents essentially the now-canonical NT is the presence of obeli alongside some now non-canonical texts (which can be seen in Table 1 above).

There is no indication in the Claromontanus stichometry that the obeli were original to the list: there is no indentation; the supposedly disputable texts are not 
grouped together at the end as one might expect of categorically non-canonical texts; the dashes appear to be in a different color ink than the main text; and they are less neat than the careful calligraphy of the list - comparing the crossed T's of the main body of the list and the inconsistent shape of the dashes, one can see that the original scribe's horizontal strokes were neater, thinner and more consistent than those of the inserted obeli. All of this collectively suggests that the obeli - the only indication that there is something distinct about the six marked texts - were added at a later time than the stichometry and in a different hand. If this is indeed the case, the list originally (that is, as early as the sixth century, with the possibility of an older exemplar) set forth a NT that included Barnabas, the Shepherd, the Acts of Paul and the Revelation of Peter.

I suggest an alternative to what has long been the narrative surrounding the Claromontanus stichometry. Following Tischendorf and Verheyden's brief suggestions, the obeli placed by Judith, 1 Peter, Barnabas, the Shepherd, the Acts of Paul and the Revelation of Peter were inserted by a later hand than the one that transcribed the list. Aside from the obeli, there is nothing else in the list to indicate questionable status - no difference in the titles, no indentation, no break in the stichometric numbering. The positive evidence of the visible distinctions between the main list and the obeli along with the negative evidence of a lack of other markers of disputed status suggests that the obeli are a later addition.

Regarding the dash placed by ad petrum prima - which is indistinguishable from those by Judith, Barnabas, the Shepherd, the Acts of Paul and the Revelation of Peter, none of which appear to denote a new section - this mark represents a reaction against the odd title: ad petrum prima, rather than prima petri epistula (or some variation thereof). The 'obelizer' perhaps realized their mistake upon reading the next title and coming to the conclusion that these are likely the letters of 1-2 Peter, rather than some possibly unknown apocryphal Petrine text of questionable status similar to that of Barnabas and the others that were marked. ${ }^{15}$ Furthermore, the placement of the Acts of the Apostles, whose status remained stable, among what are otherwise disputed texts is a further indication that the dashes are supplementary to the stichometry: the logic of Acts' placement appears to be that it is included within close proximity to another book of Acts (the Acts of Paul), rather than situated with either Luke (as a two-volume work or following the four gospels in the common association of gospels-Acts) or with the catholic epistles (as a narrative and epistolary apostolic collection). Regarding the logic of the stichometry's ordering of books, it appears that Barnabas may be listed as an eighth catholic epistle, ${ }^{16}$ while the final five books are listed in chiastic structure: the Johannine Revelation (A), the Acts of the

15. Even if the obelus did indicate a break between the Pauline epistles and 1 Peter, as Metzger suggests, this would further underscore the secondary addition of the obeli due to the break in convention with the rest of the stichometry.

16. Origen even called Barnabas a 'catholic epistle'; see n. 5 above. 
Apostles (B), the Shepherd (C), the Acts of Paul (B'), and the Revelation to Peter (A') - still further evidence in favor of the original inclusion of the four 'obelized' texts.

On this basis, the inclusion of these four now-extracanonical texts can be considered original to the Claromontanus stichometry, which presents a 27-book list representing a possible 31-book NT collection that included Barnabas, the Shepherd, the Acts of Paul and the Revelation of Peter. Like Eusebius's vó $\theta \alpha$ grouping, which includes Barnabas, the Shepherd, the Acts of Paul and the Revelation of Peter (with the Didache and the Gospel according to the Hebrews in addition), the Claromontanus stichometry suggests that these texts had been considered useful, rather than rejected (by Eusebius as well as by whoever placed the obeli alongside those texts in Codex Claromontanus) on a theoretical basis. Even if the obeli were quickly added, perhaps within the same generation of the list's transcription into the codex, this nevertheless points to a scribe who in the sixth century - remarkably late in the traditional account of the canonical process - copied a 27-book NT alternative to the now-canonical collection into a codex containing 14 Pauline texts (including Hebrews). It cannot be taken for granted, as it has been in the past, that this stichometry presents a NT canon equivalent to (or, perhaps especially, intending to be) the now-canonical collection.

\section{Conclusion}

The Claromontanus stichometry is a puzzling list for three main reasons: its anomalous exclusion of four Pauline texts, odd titles for 1-2 Peter, and the insertion of an obelus alongside one OT text and five NT texts that supposedly indicates disputed status. It is likely, given the early interest in the Pauline epistles and the association by the end of the third century of the catholic epistle collection, that the omission of Philippians, 1-2 Thessalonians and Hebrews, as well as the mislabeling of 1-2 Peter as ad petrum prima and ad petrum II, are genuine errors. Most visibly obvious is that, while the main list is in brown ink and clearly inscribed with neatness and care, the obeli appear to be written in a darker ink and to have been penned more hastily, as their width and length appear uneven. The main scribe uses regular lines, as seen most clearly in his consistently formed crossed T's; the 'dispute' marks show no such care. The obeli were later additions, and the mark alongside ad petrum prima should be accounted for not as a mark indicating the start of a new section following the Pauline letters, but rather one indicating a later user's awareness of this unexpected mistitle. The obelus alongside Judith is difficult to explain, but the obelizing scribe may have marked it in accordance with Jerome's comment about its apocryphal status in his preface to the Vulgate text. ${ }^{17}$

17. See n. 13 above. 
It is only possible to finagle out of this stichometry a list that closely resembles the NT canon of Athanasius - and therefore the eventually canonical NT by taking for granted a number of inherited assumptions. Much of the preceding scholarship on this stichometry displays the dual misunderstandings that there are four obeli, marking only (and all of) the now-extracanonical texts, and that they are original to the list's transcription into the Codex Claromontanus. These misunderstandings continue to be reproduced in current scholarship on the NT canon. Contrary to the simultaneous claims that the stichometry was copied carelessly, that the obeli are original and intentional, and that the stichometry means to present the 27 books of the now-canonical NT, the obeli are a later addition, meaning that the Claromontanus stichometry originally (at least in its sixth-century context) presented a NT comprised of an alternative list of 27 books which included 23 of the now-canonical NT texts (omitting Philippians, 1 and 2 Thessalonians and Hebrews), as well as Barnabas, the Shepherd, the Acts of Paul and the Revelation of Peter. Such a NT list demonstrates a lasting interest in alternative scriptural texts and the continuing elasticity of the NT canon. ${ }^{18}$

\section{References}

Brakke, David

2010

'A New Fragment of Athanasius's Thirty-Ninth Festal Letter: Heresy, Apocrypha, and the Canon', HTR 103.1: 47-66.

Ciletti, Elena, and Henrike Lähnemann

2010 'Judith in the Christian Tradition', in Kevin R. Brine, Elena Ciletti and Henrike Lähnemann (eds.), The Sword of Judith: Judith Studies across the Disciplines (Cambridge: Open Book Publishers): 41-65.

De Boer, E.A.

2014 'Tertullian on "Barnabas' Letter to the Hebrews" in De pudicitia 20.1-5', VC 68.3: 243-63.

Dormandy, Michael

2018

'How the Books Became the Bible: The Evidence for Canon Formation from Work-Combinations in Manuscripts', TC 24: 1-39.

Gallagher, Edmon L., and John D. Meade

2018

The Biblical Canon Lists from Early Christianity (Oxford: Oxford University Press).

18. I would like to thank Francis Watson, Garrick Allen, Hugo Lundhaug and the participants of the June 2018 seminar in Oslo of the Authoritative Texts and their Reception research school, and the anonymous JSNT reviewers for their helpful feedback on earlier drafts of this article. This article has received funding from the European Research Council (ERC) under the European Union's Horizon 2020 research and innovation programme (grant agreement No 847428). 
Hahneman, Geoffrey M.

1992 The Muratorian Fragment and the Development of the Canon (Oxford Theological Monographs; Oxford: Oxford University Press).

2002 'The Muratorian Fragment and the Origins of the New Testament Canon', in Lee M. McDonald and James A. Sanders (eds.), The Canon Debate (Peabody, MA: Hendrickson Publishers): 405-15.

Harnack, Adolf von

1893

Geschichte der altchristlichen Litteratur bis Eusebius IV (Leipzig: J.C. Hinrichs).

Klostermann, Erich

1899 Origenes Werke, vol 10.1-10.2 [Die griechischen christlichen Schriftsteller 40.1-40.2 (Leipzig: Teubner, 10.1:1935; 10.2:1937)]: 10.1: 69-304; 10.2: 305703. Last accessed from http://stephanus.tlg.uci.edu 13 November 2019.

Loba Mkole, Jean-Claude

2016 'Intercultural Construction of the New Testament Canons', BT 67.2: 240-61.

Metzger, Bruce M.

1997 The Canon of the New Testament: Its Origin, Development and Significance (Oxford: Clarendon Press).

Nienhuis, David R.

2007

Not by Paul Alone: The Formation of the Catholic Epistle Collection and the Christian Canon (Waco, TX: Baylor University Press).

Robbins, Gregory A.

1986 'Peri Ton Endiathekon Graphon': Eusebius and the Formation of the Christian Bible (PhD Thesis, Duke University, USA).

Souter, Alexander

1935 The Text and Canon of the New Testament (London: Duckworth).

Tischendorf, Constantin von

1852 Codex Claromontanus, sive Epistulae Pauli omnes Graece et Latine: ex codice Parisiensi celeberrimo nomine Claromontani plerumque dicto, sexti ut videtur post Christum saeculi / nunc primum edidit Constantinus Tischendorf (Leipzig: Brockhaus).

Verheyden, Joseph

2013 'The New Testament Canon', in James Carlton-Page and Joachim Schaper (eds.), The Cambridge History of the Bible: From the Beginnings to 600, I (Cambridge: Cambridge University Press): 389-411.

Westcott, Brooke F.

1855

A General Survey of the History of the Canon of the New Testament During the First Four Centuries (Cambridge: Macmillan).

Young, Francis M.

Biblical Exegesis and the Formation of Christian Culture (Cambridge: Cambridge University Press).

Zahn, Theodor

Geschichte des Neutestamentlichen Kanons, II (Leipzig: A. Deichert). 